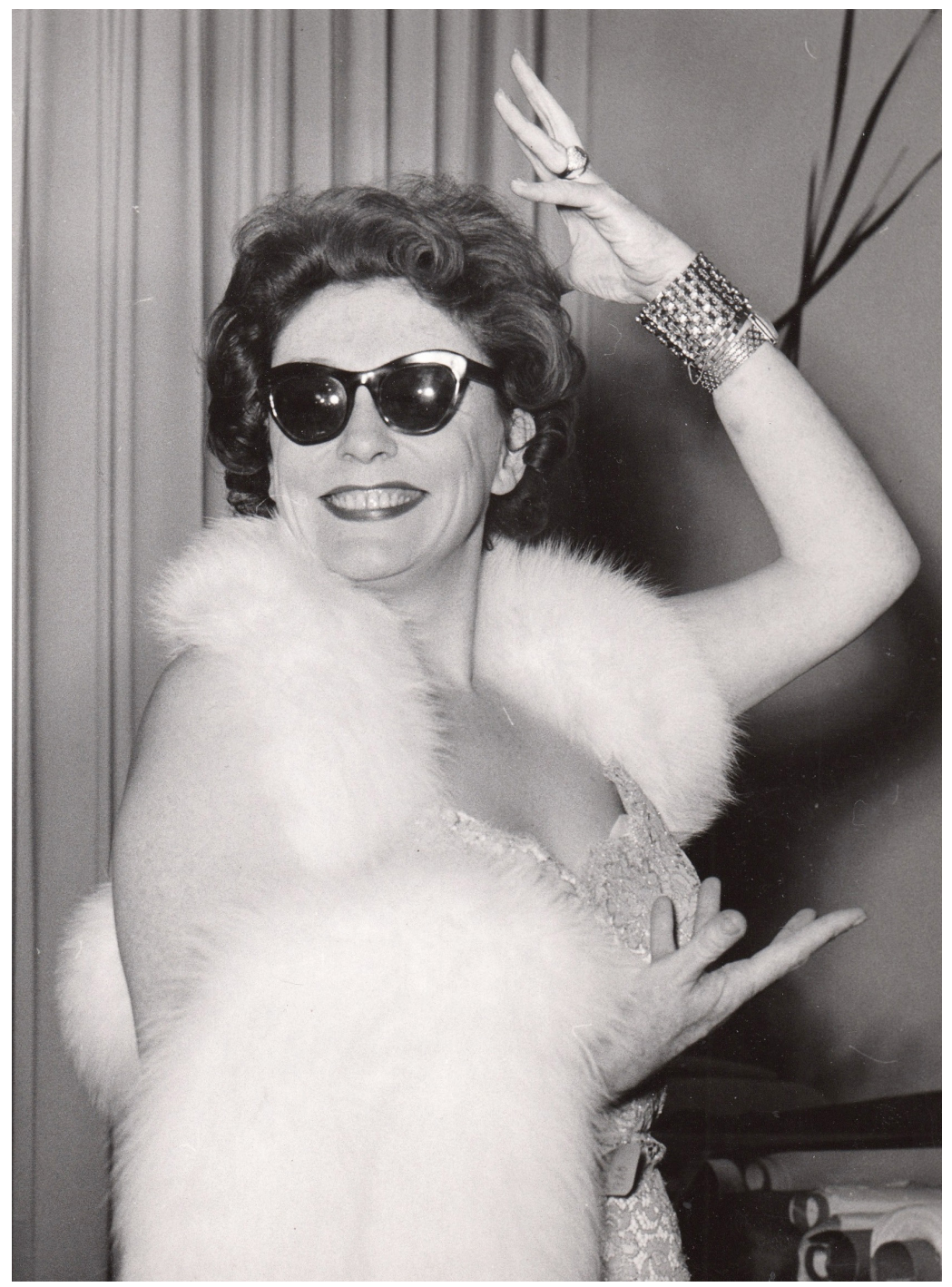

Zarah Leander after a concert at Waldbühne in Berlin, July I957. Archiv Paul Seiler Berlin, http://www.zarah-leander.de. Photographer: Georg Ebert. Copyright CC-BY-NC-ND: Paul Seiler, Sammlung Seiler Berlin. www.zarahleander.de 


\section{Queer Feelings: Zarah Leander, Sentimentality, and the Gay Diva Worship}

The Swedish actress and singer Zarah Leander (I907-I98I) may have been the most complex star in Nazi German cinema. She never offered any excuses or explanations for what she did during the years she was active in Nazi Germany, calling herself "a political idiot" who just wanted to work and make money, no matter where and under what circumstances. Three celebrated female stars, Kristina Söderbaum, Zarah Leander, and Lilian Harvey, political idiots or not, played a crucial role in Joseph Goebbels's entertainment industry. ${ }^{\mathrm{I}}$ The money the Nazi regime made through them was immediately allocated to the German war effort.

The official start of Leander's stage career took place in I929 in the popular theatre of Ernst Rolf. She then performed in a variety of films and theatrical productions. From I 936 until I 943 she was based in Berlin and starred in Nazi cinema. In I943 Leander moved back to Sweden and as a result fell out of favor with the Nazi propagandists. She was banned from appearing in Sweden, Austria, and Germany until I948, but her legendary comeback concerts in Malmö, Stockholm, and Berlin in I 949 returned her to the public's favor. Leander's schlager repertoire, dark voice, and performance style made her a celebrated entertainer in the I950s and I960s. Even to this day she remains an icon in the gay community. ${ }^{2}$

The political shame of being an ex-Nazi star never left Leander. The argument that what she did was "only entertainment" was not sufficient to explain away all her years working in the Nazi film industry. But, as Antje Ascheid points out, female movie stars are in many ways the antithesis of the prototypical Nazi female, and so Leander appears as one of Nazi cinema's most contradictory

How to cite this book chapter:

Rosenberg, Tiina 20I6. Queer Feelings: Zarah Leander, Sentimentality, and the Gay Diva Worship. In: Rosenberg, Tiina Don't Be Quiet, Start a Riot! Essays on Feminism and Performance. Pp. 80-98. Stockholm: Stockholm University Press. DOI: http://dx.doi.org/IO.I6993/baf.d. License: CC-BY 4.0 
figures. ${ }^{3}$ Ascheid claims that Leander's star persona has always been a pleasurable negotiation of antagonistic positions and spectatorship issues, strikingly articulated through her immense popularity in the post-war gay community. ${ }^{4}$

Queer feelings have been linked to diva worship with regard to the "phenomenon Leander" in the post-war period in Sweden, Germany, and internationally. The queer quality of Leander is to be found in the transgressive erotic representation of her vocal gender ambiguity, recast through gay male diva worship as counter-political resistance to "normalcy," although she also had a lesbian following. ${ }^{5}$

\section{The queer diva}

The diva has a special place in gay male aesthetics. The extraordinary, tragic, comic, angry, nasty, glamorous, provocative, sentimental, and intelligent diva is generally a straight, but not necessary heteronormative, woman. Gay divas like Maria Callas, Joan Crawford, Bette Davis, Marlene Dietrich, Greta Garbo, Judy Garland, Zarah Leander, Madonna, Bette Midler, Asta Nielsen, Birgit Nilsson, Edith Piaf, and Barbra Streisand, to a name a few in the West, are all artists who have challenged both social norms and heteronormative femininity.

The diva sometimes has a lesbian address, or at least a strong lesbian subtext, as do Asta Nielsen, Greta Garbo, Marlene Dietrich, and Zarah Leander. This subtext is expressed through a specific gender appearance, female bonding, and the "sapphonic" voice, a term coined by musicologist Elizabeth Wood. ${ }^{6}$ Diva worship is not merely about a traumatic shame community; it is also a form of queer cultural resistance. One of the aesthetic products of closet culture, a Verfremdung of heteronormativity, is camp, an old, community-based communication system mainly found in gay male culture. Divas and a specific musical repertoire are its cornerstones. ${ }^{7}$ In the I970s the Swedish gay men's magazine Revolt wrote: "Zarah Leander was so popular that many gay men publicly stated that they disliked her because they did not want to be branded as gay." ${ }^{8}$ Diva worship can have many reasons, and the adoration of gender ambiguity connected to sexual ambivalence is one of them. Leander's greatest fan, Paul Seiler in Berlin, states: "We were addicted to Zarah for her pathos-filled 
style, for her larger-than-life emotional outbursts, for her Valkyrie appearances, dark, almost masculine voice. For many of us she was both father and mother; she was also the surrogate drug for all our closeted emotions." "Seiler has explained the specifics of his Leander adoration at length:

She was the great star and acted so perfectly at live performances. She did not enter the stage; she took up the whole space. She had an aura of loftiness about her. The statuesque body emphasized her charisma, and only the wide gestures of her arms and hands brought some movement into her performances. She raised her arms towards the end of the song as if she wanted to say "This is me and that's it!"

Richard Dyer, who has written about the worship of Judy Garland at mid-century, says that when Garland was fired by MGM in I950 and tried to commit suicide, "It constituted for the public a sudden break with Garland's uncomplicated and ordinary MGM image, made possible a reading of Garland as having a special relationship to suffering, ordinariness, normality, and it is this relationship that structures much of the gay reading of Garland." I952 she abandoned her film career and started making concert appearances, beginning at the London Palladium. Dyer claims that post-I950 readings of Garland were anachronistically shifted back into her earlier films, recordings, and biography in the light of her subsequent history. ${ }^{\mathrm{I2}}$ Television and repertory cinemas that specialized in nostalgic revivals facilitated both Garland and Leander's careers as entertainers. ${ }^{\mathrm{I}}{ }^{3}$

\section{The diva of shame}

Sweden both profited from World War II and emerged from it with an intact infrastructure. As the ex-star of Nazi German cinema Leander was one of the few public figures in Sweden to be accused of Nazi sympathies at the time. "What shall we do with shame? " the queer scholar Michael Warner once asked rhetorically, and answered: "Put it on somebody else!" ${ }_{44}$ The individual experience of shame might feel like a personal and private emotion, but it is also a public phenomenon. The stigmatized individual is observed; she/he is highly visible and cannot hide 
from the gaze of fellow citizens. Shame as a negative self-image is linked to social or political repercussions, or both, that turn it into a social act. The visibility of shame is the outcome of violating social norms.

Same-sex desires and sexualities are one form of social norm violation that bears a special relationship to gender. While the specificity of Leander's shame and its public impact are linked to her past in Nazi Germany, she also embodied Swedish catharsis as a visible scapegoat after the war. She was covered in shame. With the rest of the nation pointing to her, she could feel free of collective guilt for any Nazi sympathy shown during the war. The idea of Sweden as a small, innocent nation surrounded by large and powerful enemies has only occasionally been questioned. ${ }^{\text {is }}$ Therefore, the national narrative of innocence is illuminating in the catharsis that the instance of Leander provided. That narrative demanded a scapegoat, and by appointing one the Swedish nation was symbolically purified through her shame. As the feminist scholar Sara Ahmed points out, "By witnessing what is shameful about the past, the nation can 'live up to' the ideals that secure its identity or being in the present.” ${ }^{16}$

However, the social norms Leander violated concerned not only her dubious past. Her persona was also provocative in itself. The Leander performances of Kann denn Liebe Sünde sein?; Nur nicht aus Liebe weinen; Ich weiß, es wird einmal ein Wunder gescheh'n; Jede Nacht ein neues Glück; Waldemar; Yes Sir; and Merci, mon ami, es war wunderschön, to mention only a few of the songs that made her the gay icon of the I950s and I960s, together with her ambiguous gender, enabled a gay identification and desire across heteronormative gender boundaries. Gay men have historically had difficulties identifying with hegemonic forms of masculinity. In Leander's case the diva, "the fallen woman," emerges from certain forms of closet culture - and later also openly gay culture as a stand-in for the gay male. In her songs and in her habitus Leander broke various taboos. Her frankness in confronting social, sexual, and gender norms resonated with many in the Swedish and international gay communities. Guido Knopp comments that the mixture of Übermutter and vamp guaranteed her the love and adoration of her gay audience. ${ }^{17}$ 
Queer scholars J. Jack Halberstam, Eve Kosofsky Sedgwick, and others who have written extensively about gay shame, posit an early childhood experience of sexual shame that has to be reclaimed, reinterpreted, and resituated by a queer adult who, if armed with theoretical language about her or his sexuality, can transform past experiences of abjection, isolation, and rejection into legibility, community, and love. ${ }^{18}$ Halberstam writes:

Gay shame, in this scenario, becomes the deep emotional reservoir upon which an adult queer sexuality draws, for better or for worse. And the sexual and emotional scripts which queer life draws upon, and which oppose the scripts of normativity, are indebted oddly to this early experience with shame, denial, and misrecognition. When we seek to reclaim gay shame and we oppose the normativity of 'gay pride' agenda, we embrace these awkward, undignified, and graceless childhoods and we choose to make them part of our political future. ${ }^{19}$

As Brett Farmer observes, "Much of the breathtaking success with which mainstream culture is able to install and mandate a heteronormative economy depends directly on its ability to foster a correlative economy of queer shame through which to disgrace and thus delegitimize all that falls outside the narrow purview of straight sexualities." 20

\section{Diva worship as a reparative position}

According to the testimony of gay contemporaries, Leander's intense, almost male contralto was at its best when it expressed troubled love, fear of isolation, and persecution. In a review of her 1937 film Zu neuen Ufern (To New Shores), Der Berliner Lokalanzeiger wrote: "What dominates the film is the shimmer of Leander's voice: a voice as intoxicating as heavy, dark wine ... as powerful as the sound of an organ ... as transparent ... as glass, as deep as metal. Everything is in this voice: jubilation, happiness, the drunken melody, and the wild pain of life." ${ }^{21}$ Erica Carter finds that what is noteworthy in this reviewer's representation of the effects that Leander's voice had on film spectators was the mention of qualities that bourgeois aesthetics attribute not to the beautiful, but to the sublime. 
Accounts of the sublime since Kant have emphasized both its dynamism (the Kantian sublime 'moves', whereas the beautiful produces 'quiet contemplation'), and its ambivalence (hence the Kantian Abgrund, or abyss). Leander's voice operates, this review suggests, in a similar mode, stirring the very body of a spectator in whom it produces 'jubilation', certainly, but also jubilation's darker aspects: 'drunken melody', 'wild pain'. ${ }^{22}$

Farmer takes this notion even further, with the concept of "queer sublimity." Gay historian Daniel Harris finds that at the heart of gay diva worship is the almost universal homosexual experience of ostracism and insecurity, and the desire to elevate oneself above one's antagonistic surroundings. ${ }^{23}$ Wayne Koestenbaum similarly claims that "gay culture has perfected the art of mimicking a diva of pretending, inside, to be divine - to help the stigmatized self imagine that it is received, believed and adored." ${ }^{24}$

Farmer writes in similar terms that "tuned to the chord of reparative amelioration, diva worship emerges here as a practice of resistance, queer utopianism, or what might be more suggestively termed queer sublimity: the transcendence of a limiting heteronormative materiality and the sublime reconstruction, at least in fantasy, of a more capacious, kinder, queerer world." ${ }^{25}$ Kosofsky Sedgwick calls these survivalist dynamics of queer culture "reparative" in the sense given to the term in object relation theory as an affirmative impulse to repair or make good the losses of subjective constitution. "Because there can be terrible surprises, however, there can also be good ones. Hope, often a fracturing, even traumatic thing to experience, is among the energies by which the reparatively positioned reader tries to organize the fragments and part-objects she encounters and creates." ${ }^{26}$

\section{Diva with a voice}

Carter notes that in a song dripping with the pathos of parting and loss, Leander's voice derives melodramatic intensity from the use of close sound and the absence of ambient noise. According to Carter, in her I930s films the visual figuring of Leander as a singing body, and her various narrative positionings as a revue or 
opera diva, recording artist, or music-hall star, serve to reproduce an "image of corporeal unity" between body and voice as a key source of the "auditory pleasure." 27 The harmonious integration of spectator and film text through the fixing of voice to body image is also reinforced by Leander's vocal capacity for depth and resonance - qualities that embrace her cinema audience within a "sonorous envelope." 28

Carter claims that Leander's singing voice breaks the link between body and voice, both by a spatial treatment that ruptures their unity, and by a textual structure that situates the musical number, rather than the narrative, as the fulcrum of dramatic development. ${ }^{29}$ She writes that the genre shift from Musikfilm to Schlagerfilm was evident in Leander's Ufa productions on several occasions and became her specialty in the I950s and I960s.

In these slippages it becomes evident how Leander's voice begins to detach itself from the diegetic and visual spaces of the film text, and to assume the identity it possesses within the public space of mass culture as a disembodied acoustic presence. For if the first apparatus of representation that displaces Leander's voice from its location in the individual film text is genre, then the second is the culture of Schlager, or hit song itself as it developed within the popular music industry in tandem with sound film. ${ }^{3 \circ}$

Leander's particular transgender appeal resided in her distinctive voice. Described as baritone, sometimes as bass, it entered an "unnatural," inadmissible range that could signal an erotic dissonance or queerness. ${ }^{3 \text { I }}$ Elizabeth Wood's characterization of what she calls the "sapphonic voice" - the voice that signifies lesbian difference and desire - can equally apply to Leander's flexible negotiation and integration of an exceptional range of registers. Leander crosses boundaries among different voice types and their representations to challenge polarities of both gender and sexuality as these are socially - and vocally - constructed. ${ }^{32}$

Alice A. Kuzniar writes that Leander's "phantasmatic voice indeed recreates, by transgendering, the body, particularly to have it imitate her model, only in reverse, now male-to-female. Indeed, the two Zarah-impersonators that I have heard perform 
live, Christina and Tom Fisher, are so remarkable because their haunting and haunted voices possess the phantasmatic capacity of evoking Zarah's presence: in this gender-bending reincarnation, a woman's masculine voice thrillingly issues from a man's body." ${ }_{33}$

\section{Schlager and the perverse sentimentalist}

The shift from cinema to the culture of schlager was presaged by Leander's vocal performance in her films. She moved in the postwar period from cinema to live performance with songs and schlager. The latter is a popular genre that has never been expected to generate highbrow interest. It represents sentimentality with the decaying fragrance of the dancehall and shattered dreams. Schlager is both banality and magnificence rolled into one, with the two often intimately connected: "I love you, I miss you, I can't live without you!" All this is easier to express when someone sings these words that can be so hard to say. Like many other genres, schlager is an emotional messenger.

Schlager has a special, highly ambiguous relationship to modernity and modernism. On the one hand, schlager music is dependent on modern media and technology such as radio, microphones, recordings, and cinema. On the other hand, it is often characterized as anti-modern in its appeal to old-fashioned feelings and its dependency on obsolete conventions. Schlager originated in nineteenth-century Viennese operetta and chapbooks. The latter were often dramatic and gory, with violent death perpetually lurking on the next page, unlike what would eventually constitute genuine schlager, which was mainly about longing and being (unhappily) in love.

Schlager is sentimental popular music, if one defines sentimentality as exaggerated emotionality, insincerity, and something generally of low aesthetic standing. Modernism initiated a shift in values, which Rita Felski has characterized as a "cultural remasculinization." ${ }_{4}$ The emotionality that had previously been common to both sexes was not feminized until the emergence of modern Western culture, at which time a detached, non-emotional approach attained a higher status than emotionality, which was increasingly associated with pretense and sexuality. Terms such 
as sentimental, melodramatic, theatrical, and romantic were increasingly given negative connotations and thought of as referring solely to beautiful illusions or exaggerated emotional expression, as opposed to critical analysis.

Deborah Knight has analyzed the categorical negation of sentimentality in philosophy of art. ${ }^{35}$ Sentimentality is often associated with soft, comforting, tender feelings such as care, sympathy, affection, and empathy. While these feelings may not immediately arouse protests from aestheticians, the direction these affects take in sentimental pleasure does. Anti-sentimental critics claim that sentimentality is a case of boundless and uninhibited delight that is simply tasteless. According to Knight, standard anti-sentimental philosophic opinion condemns sentimentality as immoral and unworthy.

The critics of sentimentality, Joseph Kupfer among them, primarily object to sentimental pleasures, which they describe as perverse, excessive, and repetitive. ${ }^{36}$ The consumer of sentimental art repeatedly watches the same sentimental films, listens to the same sentimental music (including melodramatic bel canto arias and bombastic Wagner overtures), and indulges in sentimental pastimes. Kupfer claims that sentimentality is a character fault, rather than an aesthetic expression. ${ }^{37} \mathrm{He}$ views the sentimentalist with repulsion as a perverse, self-centered person who wallows in a sentimental flood of emotions. For Kupfer the object of sentimentality is the sentimentalist her or himself.

\section{Sentimentality and kitsch}

Schlager has a bad reputation because of its kitsch aesthetics. Those scholars and theorists who associate sentimentality with kitsch, and especially the ones who do so with a political agenda, position sentimentality in a cultural and political context that goes beyond loving and tender feelings. Although there is no consensus regarding the definition of kitsch, the term has had a negative connotation ever since it was coined in Germany around the middle of the nineteenth century. Kitsch has been synonymous with worthless, commercial, mediocre, or simply bad art. But not all substandard art qualifies as kitsch, nor should kitsch be seen 
unconditionally as artistic failure, something in which everything went wrong..$^{8}$

Both schlager and kitsch are often defined as "bad taste," although it has been hard to identify exactly what constitutes this bad taste. Kitsch forms an aesthetic category of its own. It shares with queer the status of being culturally undesirable. Like queer, kitsch has been banished into the shadows of negative cultural history, the domain of the invisible and inaudible. Similar to the way in which sentimentality is denied and described as perverse, the disdain for kitsch appears to create a special form of cultural and artistic "unpresence" that constantly calls attention to itself, but must be disregarded in order not to sully normative, great art and culture.

Although the aesthetic content of high culture consists of the fine arts, that content has occasionally been extended to include more popular expressions of art. Unsophisticated junk, however, the refuse of the art world, has a very special and unique allure. The philosophers and cultural theorists who gravitated around the Frankfurt School criticized mass culture and its devastating effects with reference to Nazism. Kitsch in this analysis was a fundamentally despised element. In a definitive essay on kitsch theory entitled "Einige Bemerkungen zum Problem des Kitsches" (Some Comments on the Problem of Kitsch), Hermann Broch designates kitsch as the evil element in the value system of art. ${ }^{39}$ Aesthetically, kitsch is associated with subject matter such as weeping children and sunsets in cheap poster art. Common to all kitsch products is that they are variations on the theme of beauty and are often exceedingly charged with emotional, sentimental stereotypes that "spontaneously" arouse pre-programmed responses, such as tears. Typically, the subject is rendered in a way that makes it easy to identify as kitsch. Kitsch is a mirror that reflects the desires and fears of the person who stands before it. Kitsch is something that actively engages the beholder. ${ }^{4}$

With their shifting and heavy expressions of longing, Leander's emotive schlager performances belong to the category of escapism, imagination, melodrama, and sentimentality. Sentimentality is the distinguishing feature that sets kitsch apart from other expressions of popular culture. The Frankfurt School and subsequent critics 
of kitsch have disparaged it and sentimentality on the grounds that they both are an opiate of the people in the Marxist sense. A kitsch-oriented person's way of relating to the world, unlike that of the discerning consumer of culture, is conditioned by "lascivious absorption and merging." ${ }^{4}$ If the aesthetics of schlager belong to the world of kitsch, it is nevertheless enjoyed in gay culture as camp, one of the most visual expressions and resistance strategies of gay culture. It has served as a haven for gays by being a refuge from heteronormativity. ${ }^{42}$

\section{The shameless stickiness of pleasure}

Leander's comeback and golden era were in the I950s and I960s, but by 1958 she wrote that the diva was dead:

There are no divas today. Not the divas we read about in our childhood, whom we worshipped on stage and screen. Not the divas buried in flowers who proffered their bejeweled hands to hand-kissing gentlemen, not the divas who sauntered along the boulevards escorted by infatuated adorers and a brace of hounds. How did the celebrated diva die? Well, it happened so fast. One fateful day, the diva went down to the store to buy some bread for breakfast - and on that day she died, never to live again. ${ }^{43}$

In the I970s, the gay movement discovered its own political songs. In a more open political context, many people experienced Leander worship as stale and outmoded, a remnant of the closet culture. Yet the diva cult has survived in male gay culture to this day. The link to the I950s Leander worship has been sustained in the works of Rainer Werner Fassbinder. Two of Leander's most famous films, Zu neuen Ufern and La Habanera, were also among Fassbinder's favorites. They were both directed by Detlef Sierck, later known as Douglas Sirk. Kuzniar writes that "As is well-known, Sirk's melodramas were Fassbinder's most influential models, and the latter's essay on the master's I950s Hollywood films demonstrates how he (ir)reverently read them as camp." ${ }_{44}$ Kuzniar claims that Leander's transvestetic performance of femininity is echoed in several of Fassbinder's characters. "Queer German cinema follows a circuitous route indeed from Nazi melodrama to Fassbinder's 
transgendered fantasies." 45 In Sweden the Leander tradition has been continued by the drag group After Dark, which has recreated acclaimed Leander acts in its shows since the late I970s.

Ludwig Giesz has characterized the self-centered and uninhibitedly pleasure-oriented sentimentalist experience as a perversion aimed at self-gratification (Selbstgenuss). ${ }^{46}$ Some art scholars and philosophers, such as Kathleen Higgins and Robert C. Solomon, speak of "sweet kitsch" and want to shift the focus from the objects of pleasure to what they consider to be the essential aspects of kitsch, namely, the response and the experience. ${ }^{47}$ Higgins claims that kitsch and non-kitsch objects arouse the same kinds of feelings. What sets the two categories apart is not the experience itself but that some are drawn to kitsch, while others shy away from its unsophisticated and blatant sentimentality. Solomon also places value on the tender feelings that the sentimental experience evokes, rather than sentimentality itself. ${ }^{48}$

A key to understanding the resistance that sentimentalism arouses may lie in the "stickiness" (Klebrigkeit) of schlager and the sentimental genres. All music is penetrating, but kitsch sentimentalism has an appeal that wields an astonishing, compelling force. It bypasses reason and goes straight for the feelings. This ability pierces us whether we try to resist it or not. In "Der Fall Wagner" Nietzsche writes that Wagner's music not only attacks the listener but persuades the nerves (die Nerven überredet). ${ }^{49}$ Such overwhelming compositions operate bodily-physically in approximately the same way as drugs or ecstatic sex.

Schlager merges the worlds of sexuality and sentimentality: tears, body, and sensuality form a unity that does not loosen its grip, which is why it is said that schlager is sticky and cannot be shaken off. Sticky things, like bodily effluents, are soft, flowing, and flexible. They shape themselves according to movement. In the same way that they mix the positions of subject and object, they are on the one hand passively receptive, and on the other actively penetrating. In short, stickiness symbolizes the sensual and sexual being and the concrete experience of this sensuality.

The sentimental schlager experience includes an embracing of stickiness as an essential element. Alongside the concrete sensual participation - especially sing-alongs binding others together in 
the same subculture - there is also the revelation of the sticky boundary that "the kitsch person" (der Kitschmensch) transcends by singing schlager. The resulting experience transcends detached observation and penetrates the skin, entering every bodily pore.

Modern Western masculinity is intimately associated with self-control. Claes Ekenstam writes that, "Men should be strong, upright, and guided by common sense. Chest out, stomach in, and teeth firmly clenched, men should walk straight ahead with a steady gaze, whether they are marching as soldiers for their country or navigating the pitfalls of their career. Under no circumstance must they fall!" ${ }_{50}$ In the eyes of heteronormativity, gay men who relish schlager and may occasionally lapse into tears appear to challenge contemporary masculinity. According to Ekenstam, they are, in fact, resurrecting an older tradition in Western cultural history, when men's tears flowed freely. In the Bible as well as in the Odyssey men shed tears. The renaissance poet Petrarch believed in the cathartic power of tears. Goethe's pre-romantic Sturm-und-Drang hero Werther was forever resorting to tears and in fact suffered from sudden fits of swooning. However, a growing emphasis on male self-control has created a negative attitude toward male tears, until they have come to be seen as a sign of weakness that reveals an underlying lack of masculinity. ${ }^{51}$

The gay male schlager and diva culture can be interpreted as a defense of sentimental culture, which it embraces as a source of power and joy. Leander's concerts were one of the few places where gay men could meet and socialize openly in the I950s and I960s in Sweden and Germany. The ageing, abject, and monumental Leander, with her jewelry, wigs, and makeup, was received with open arms by the gay community. ${ }^{52}$ In Paul Seiler's words of homage: "I turn to the immortal Zarah and I can see her with her majestic head high and with a proud, but sad look in her eyes; and I hear the dark, raw timbre of her voluminous organ voice with its capacity to raise trivial entertainment to nobleness." ${ }_{53}$

\section{Notes}

I. Ascheid, Hitler's Heroines, 8.

2. Ibid., I 55. 
3. Ibid., 2 I 7.

4. Ibid., 9 .

5. Kuzniar, Queer German Cinema, 62.

6. Wood, "Sapphonics."

7. Heteronormativity as a concept is used to analyze the structural privileges associated with heterosexuality. For the concept of camp, see Cleto, Camp: Queer Aesthetics.

8. Holm, “Bögarnas Zarah,” I6.

9. Seiler, Zarah Leander, 8; Rosenkranz \& Lorenz, Hamburg, I32.

ı. Seiler, Zarah Leander, Io9.

I I. Dyer, “Judy Garland,” I 38.

I2. Ibid., I39.

I3. Ibid.

I4. Warner, Normal, 3.

I 5. Boëthius, Heder och samvete.

I6. Ahmed, Cultural Politics, Io9.

I7. Knopp, Hitlers Frauen, 30.

I8. Halberstam, "Queer Studies," 63.

I9. Ibid. The attachment of shame to queer has been a large part of several influential projects in Queer Studies, including Michael Warner's critiques of "normal," Eve Kosofsky Sedgwick's theory of shame, Leo Bersani's work on "homos," and Douglas Crimp's on queer before gay. Crimp shows very explicitly that the queer is the pre-history of gay - a history that should not be left behind in the rush to embrace gay pride, but must be excavated in all its contradictions, disorder, and eroticism.

20. Farmer, "Fabulous Sublimity," I67.

2 I. Knopp, Hitlers Frauen, 296.

22. Carter, Dietrich's Ghosts, I 83-г 84 .

23. Harris, Rise and Fall of Gay Culture, Io. 
24. Koestenbaum, The Queen's Throat, I33.

25. Farmer, "Fabulous Sublimity," I70.

26. Kosofsky Sedgwick, "Paranoid Reading," I 46.

27. Carter, Dietrich's Ghosts, I92.

28. Ibid., I93.

29. Ibid.

30. Ibid., I95.

31. Kuzniar, Queer German Cinema, 63.

32. Wood, "Sapphonics," 33; Rosenberg, “Touch of Opera," 3 I.

33. Kuzniar, Queer German Cinema, 63.

34. Felski, Gender of Modernity.

35. Knight, "Sentimentality."

36. Kupfer, "Sentimental Self."

37. Ibid.

38. Broch, “Zum Problem des Kitsches.”

39. Ibid.

40. Kulka, "Kitsch," 252; Kraus, I love Dick, 2 I.

4I. Felski, Gender of Modernity, i I8.

42. Cleto, Camp.

43. Leander, Vill ni se en diva? 7.

44. Kuzniar, Queer German Cinema, 2.

45. Ibid.

46. Giesz, Phänomenologie des Kitsches.

47. Higgins, "Sweet Kitsch.”

48. Solomon, "In Defense of Sentimentality."

49. Nietzsche, "Der Fall Wagner."

50. Ekenstam, "Rädd att falla," 45.

5 I. Ibid., 55 . 
52. Kuzniar, Queer German Cinema, 276.

53. Seiler, Zarah Leander, I 83-184.

\section{Works Cited}

Ahmed, Sara. The Cultural Politics of Emotion. New York: Routledge, 2004 .

Ascheid, Antje. Hitler's Heroines: Stardom and Womanhood in Nazi Cinema. Philadelphia: Temple University Press, 2003.

Boëthius, Maria-Pia. Heder och samvete: Sverige och andra världskriget (Honor and conscience: Sweden and WWII). Stockholm: Ordfront, I99I.

Broch, Hermann. "Einige Bemerkungen zum Problem des Kitsches." In Dichten und Erkennen: Gesammelte Werke. Essays, Band I. Zurich: Rhein Verlag, I955.

Carter, Erica. Dietrich's Ghosts: The Sublime and the Beautiful in Third Reich Film. London: British Film Institute, 2004.

Cleto, Fabio. Camp: Queer Aesthetics and the Performing Subject. A Reader. Ann Arbor: University of Michigan Press, I999.

Dyer, Richard. “Judy Garland and Gay Men.” In Heavenly Bodies: Film Stars and Society. 2nd edition, I37-I9I. London: Routledge, 2004 .

Ekenstam, Claes. Rädd att falla: Studier $i$ manlighet (Afraid to Fall: Studies of Masculinity). Stockholm: Gidlunds, I998.

Farmer, Brett. "The Fabulous Sublimity of Gay Diva Worship." Camera Obscura 20 (2005): I65-I95.

Felski, Rita. The Gender of Modernity. Cambridge, MA: Harvard University Press, I999.

Giesz, Ludwig. Phänomenologie des Kitsches. Munich: Wilhelm Fink Verlag, I97I.

Halberstam, J. Jack. "Queer Studies." In A Companion to Gender Studies, edited by Philomena Essed, David Theo Goldberg, and Audrey Lynn Kobayashi, 62-72. Malsen, MA: Blackwell, 2005. 
Harris, Daniel. The Rise and Fall of Gay Culture. New York: Ballantine, I999.

Higgins, Kathleen. "Sweet Kitsch.” In The Philosophy of Visual Arts, edited by Philip Alperson, 568-58I. New York: Oxford University Press, I990.

Holm, Michael. “Bögarnas Zarah.” Revolt I I (I98I): I 8.

Knight, Deborah. "Why We Enjoy Condemning Sentimentality: A Meta-Aesthetic Perspective." In Journal of Aesthetics and Art Criticism 57 (I999): 4I I-420.

Knopp, Guido. Hitlers Frauen und Marlene. Munich: Bertelsmann, 200I.

Koestenbaum, Wayne. The Queen's Throat: Opera, Homosexuality and the Mystery of Desire. London: Penguin, I993.

Kosofsky Sedgwick, Eve. "Paranoid Reading and Reparative Reading, or, You're So Paranoid, You Probably Think This Essay Is About You." In Touching Feeling: Affect, Pedagogy, Performativity. Durham: Duke University Press, 2003.

Kraus, Chris. I love Dick. Cambridge, MA: MIT Press, 2006.

Kulka, Tomas. "Kitsch.” British Journal of Aesthetics 28 (I988): I 8-27.

Kupfer, Joseph. "The Sentimental Self." Canadian Journal of Philosophy (I996): 543-550.

Kuzniar, Alice A. The Queer German Cinema. Stanford, CA: Stanford University Press, 2000.

Leander, Zarah. Vill ni se en diva? (Would you like to see a diva?). Stockholm: Wahlström \& Widstrand, 1958.

Nietzsche, Friedrich. "Der Fall Wagner." Sämtliche Werke, Band 6. Munich: DTV, I988.

Rosenberg, Tiina. "Schlager, känslor och svensk homokultur" (Schlager, Emotions, and Swedish Gay Culture). In Queersverige, edited by Don Kulick, 336-363. Stockholm: Natur och Kultur, 2005.

. "The Touch of Opera: Or, Can a Feminist Forgive Anything for a Good Tune?" Journal of Theatre and Drama 4 (I998): 23-36. Reprinted in this volume. 
Rosenkranz, Bernhard, and Gottfried Lorenz. Hamburg auf anderen Wegen. Die Geschichte des schwulen Lebens in der Hansestadt. Hamburg: Lambda, 2005.

Seiler, Paul. Zarah Leander. Ein Kultbuch. Hamburg: Rowohlt, I98 5.

Solomon, Robert C. "In Defense of Sentimentality." Philosophy and Literature I4 (I990): 304-323.

Warner, Michael. The Trouble with the Normal: Sex, Politics and the Ethics of Queer Life. Cambridge, MA: Harvard University Press, I999.

Wood, Elizabeth. “Sapphonics.” In Queering the Pitch: The New Gay and Lesbian Musicology, edited by Philipp Brett, Elizabeth Wood, and Gary C. Thomas, 27-66. New York: Routledge, 1994. 